DOI: https://doi.org/10.47405/mjssh.v5i12.566

\begin{tabular}{|c|c|}
\hline$x=$ & Malaysian Journal of Social Sciences and Humanities (MJSSH) \\
\hline Malaysian Journal of & Volume 5, Issue 12, December 2020 \\
\hline (MJ-ssH) & e-ISSN : 2504-8562 \\
\hline & $\begin{array}{l}\text { Journal home page: } \\
\text { www.msocialsciences.com }\end{array}$ \\
\hline
\end{tabular}

\title{
Attitudes and Technology Integration among ESL Secondary School Teachers in Sabah
}

\author{
Ahmad bin Abdul Rauf ${ }^{1}$, Suyansah bin Swanto ${ }^{1}$ \\ ${ }^{1}$ Faculty of Education and Psychology, Universiti Malaysia Sabah (UMS) \\ Correspondence: Ahmad bin Abdul Rauf (mattdecro@hotmail.com)
}

\begin{abstract}
Technology integration in teaching and learning activities has become one of the among educators in recent years, especially since many countries have invested a large portion of their yearly budgets on technologies in education. As one of the developing countries, Malaysia has also spent millions and planned many programs and strategies to increase the technology integration level of teachers in schools. Despite that, the level of technology integration among teachers in Malaysia still needs a lot of improvement, especially in teachers' attitudes. This study examined English as a Second Language (ESL) teachers' attitudes towards the use of technology in the teaching of English at secondary schools in Sabah. This is crucial to assist in planning for any future programs or trainings by the relevant authorities. The study applied quantitative method and used cluster sampling to choose participants which comprised 100 of ESL secondary school teachers in Sabah Findings of the study disclosed that ESL secondary school teachers in Sabah have positive beliefs and attitudes towards technology integration.
\end{abstract}

Keywords: ESL teachers, technology integration, attitudes

\section{Introduction}

In the field of education, the growth and development especially in innovation and technology is undeniably at a rapid scale since the turning of the century. Technology, notably in Information Communication Technology (ICT) has become part of our daily life and is also considered as one of the key components of education. Over the last few decades, the importance of integrating technology into teaching and learning process is debated and researched not only among educators but to scholars as well policy makers. Through many studies and research scholars and educators suggested that technology integration improves teaching (Gilakjani, 2017), develops higher order thinking skills (Edwards, 2016) and allows teachers to create more student-centred classroom environment (Toh, Y.,2016).

Because of these expected outcomes, many countries have invested tremendous amounts of money to increase availability of technology in classrooms (Tarman, et al.,2019). Malaysia as one of the developing countries in South East Asian region through its Ministry of Education (MOE) showed the expenditure on education particularly on technology of ICT over the past two decades has skyrocketed tremendously. The government had spent nearly RM6 billion in education technology field such as smart school, which is one of the most capitals intensive investments Malaysian Education System has undertaken. 
As a powerful tool, technology would bring about a transformation in education (Chigona, 2015). However, there are challenges and barriers towards the technology implementation in education. The lack of professional development is one of them (Tondeur, et al., 2017). Studies showed that teachers who went to technology related professional development programs (in-service training) are likely to show positive attitude towards the use of technology in their teaching compared to those who don't (NEA, 2008; Gray, Thomas \& Lewis, 2010).

Teachers' negative belief and attitude toward technology are another reason for teachers' lack of technology integration in their teaching. Several studies implied that teachers' beliefs and attitude are two of the most important constructs of technology integration (Belland, 2009; Kim, Kim, Lee, Spector \& DeMeester, 2013). Teachers' beliefs and attitude contribute towards technology anxiety, which is a negative emotional state by a person when he or she uses technology or technology equipment (Bozionelos, 2001).

Technology usage for the teaching and learning in the classroom is crucial in providing opportunities for students to learn effectively in today's digital era. However, the success of technology integration in teaching and learning process highly depends on the preparation and attitude of teachers. Despite teachers' attitude important role in determining the success of technology integration in their classes, there are few studies that focus on ESL secondary school teachers' attitude towards technology integration in teaching and learning. Therefore, there is a need for further studies to examine the teachers' attitude, especially in Sabah and Malaysia. This article focuses on finding out the attitude of ESL secondary school teachers towards technology integration in their teaching. Specifically, the objectives of the study are:

i. To study the attitude of ESL secondary school teachers towards technology integration.

ii. To study the significant difference between ESL teachers' attitude towards technology integration by their gender.

iii. To study the significant difference between ESL teachers' attitude towards technology integration by their age.

\section{Literature Review}

The success of integrating technology in any educational programme endorsed by the relevant authorities depends heavily on the support, involvement, and attitude of teachers involved. If teachers do not think the programmes organised can achieve their expectations or fulfilling their students' needs, they are very much likely would not attempt to introduce and integrate technology into their teaching and learning. According to Semerci and Aydin (2018), one of the dominant factors that affects the successful use of technology or ICT in the classroom is teachers' attitude. According to Bullock (2004) teachers' attitude is the crucial factor that enables or disables them in their technology adoption. This was further supported by as study by Gonzalez \& Harrell (2018) and Andrei (2017).

\section{The factors of attitudes, gender and age on technology integration}

Attitude refers to an individual's perception of an object either positively or negatively. According to Panagiotis, et al., (2005) attitude represents mental evaluations about an object based on one's proximity or distance of it. As for teachers' attitude towards technology, it refers to teachers' selfevaluation and self-perceptions regarding how they feel about integrating technology in their own teaching practices.

Focus on teachers' attitude is essential because teachers take on a major role in deciding on the extent to which technology they use or not in the classroom, and to identify teacher negative attitude and to foster the positive ones are crucial if integrating technology in the classroom can be a success (Gilakjani \& Leong,2012). Teo, et al., (2016) also argued that the success of technology integration in the classroom heavily depends on positive teacher attitude towards it. This was also supported by Semerci \& Aydin (2018) who reiterated that teachers' attitude substantially influence their use of 
technology in the classroom. Thus, teachers' attitude play a very significant contribution towards their technology integration in the classroom.

According to Albirini (2006), attitude comprises three elements: affective, cognitive and behavioural . Affective element is the individuals' emotional case; cognitive element refers to the individuals' knowledge and behaviour element is the overt behaviour. Attitude towards technology integration is a person's general feelings towards technology or ICT and any specific computer and Internet related activities (Smith, Caputi \& Rawstone, 2000 in Abedalaziz, Sharir \& Chin, 2013). To understand about one's attitude towards technology integration, consideration of all these elements is essential.

Regarding gender's effect on attitude of teachers towards technology integration, there were some studies that show male teachers have a more positive attitude towards technology integration in their teaching (Rana, 2016, Gonzalez, et al., 2017). Other research on gender and its relation with ICT usage, although not conclusive, showed that males have more experience and able to utilise ICT or computers better (Brosnan \& Lee, 1998; Balka \& Smith, 2000). However, recent studies show how females have gained momentum towards ICT usage as shown in some research (Meelissen \& Drent, 2008, Krause, et al., 2017).

As for age related studies in ICT usage, research results in Norway by Hernes et al. (2000) discovered how about $77 \%$ of the teachers, 25 years or younger stated that they have a good command of the use of internet. There was also around $63 \%$ of the teachers, 25 years or younger have a positive attitude towards the use of the Internet in their own teaching, consistent with the findings of Liang and Chao (2002) who discovered that Taiwan younger teachers had higher literacy level on Internet compared to the much older teachers. Recent findings in Turkey, however, by Semerci \& Aydin (2018) showed that there is no significant between teachers' ICT willingness by their age.

\section{Methodology}

\section{Participants}

The study comprised 100 English Language teachers at randomly selected secondary schools in the state of Sabah. They completed the questionnaire through Google forms distributed to their respective schools.

\section{Instruments}

The study adapted the instrument from Sánchez, et al. (2012) 'In-Service Teachers' Attitude towards the Use of ICT in the Classroom" that comprised two parts. The first part included a descriptive question of the participants' gender. The second part comprised 20 items of a five-degree Likert scale (from 1- strongly disagree to 5- strongly agree). This instrument also consists of a survey on a level of satisfaction towards the training provided for the teacher. However, the researcher did not include it in the study because of its irrelevance with the context of this study. Those 20 items then factorised as three dimensions and three items had been eliminated which resulted a final 17 items, namely Cognitive (9 items) Behavioural (5 items) and Affective (3 items). To test the psychometric quality of the scale, the Cronbach-Alpha coefficient was 0.76 for scale total, which showed an acceptable level of reliability.

\section{Data Analysis}

Data analysis for this study utilised descriptive statistics, such as means, standard deviation, and reliability analysis including internal consistency coefficient (Cronbach Alpha) analysis, and univariate statistics, such as independent samples t-Test, one-way ANOVA and Scheffe as a post-hoc using Statistical Packet for Social Sciences 23 (SPSS) package program. Regarding the comparison of means in Likert-type scales, the scores were standardised based on the formula (highest score - lowest score: 
number of options: $5-1: 5=0.80$ ). Based on the interval of 0.80 , the mean scores between 1.00 to 1.80 was "very low", 1.81 to 2.60 as "low", 2.61 to 3.40 as "modest", 3.41 to 4.20 as "high", and 4.21 to 5.00 as "very high"

\section{Results}

\section{Descriptive findings on ESL teachers'attitude towards technology integration.}

The results of descriptive analysis on English Language teachers' attitude towards technology integration were presented in Table 1.

Table 1: ESL Teachers' Attitude towards technology integration

\begin{tabular}{|c|c|c|c|}
\hline Item & Component 1: Cognitive & Mean & SD \\
\hline 1 & $\begin{array}{l}\text { ICT helps me in the treatment of students with special educational } \\
\text { needs. }\end{array}$ & 4.28 & .726 \\
\hline 2 & $\begin{array}{l}\text { New technologies help me to obtain more resources to evaluate } \\
\text { students' performance }\end{array}$ & 4.38 & 632 \\
\hline 3 & The teaching methodology is enhanced using computing resources & 4.26 & .719 \\
\hline 4 & $\begin{array}{l}\text { ICT provides me access to new sources of information for my } \\
\text { teaching subject }\end{array}$ & 4.36 & .746 \\
\hline 5 & I would use internet in my classroom very often. & 4.48 & .701 \\
\hline 6 & ICT makes the attention to diversity in my classroom easy & 4.44 & .643 \\
\hline 7 & As a teacher, the use of new technologies is still difficult for me & 4.40 & .569 \\
\hline 8 & $\begin{array}{l}\text { I am willing to receive training in the use of any computing resource } \\
\text { to work in my classroom. }\end{array}$ & 4.48 & .577 \\
\hline 9 & $\begin{array}{l}\text { ICT tools such as computer and projector are necessary in my } \\
\text { classroom. }\end{array}$ & 4.44 & 641 \\
\hline & Cognitive Overall & 4.39 & .661 \\
\hline \multicolumn{4}{|c|}{ Component 2: Behavioural } \\
\hline 10 & $\begin{array}{l}\text { The integration of computing resources in the classroom encourages } \\
\text { the improvement of the teaching learning process. }\end{array}$ & 4.44 & .671 \\
\hline 11 & Students' reading abilities are improved using computing resources. & 4.22 & .927 \\
\hline 12 & $\begin{array}{l}\text { Despite limitations, I have a positive attitude towards the integration } \\
\text { of computing resources in the teaching-learning process. }\end{array}$ & 4.62 & .508 \\
\hline 13 & $\begin{array}{l}\text { Students are more motivated when using computing resources in the } \\
\text { classroom. }\end{array}$ & 4.28 & .494 \\
\hline 14 & The use of ICT increases my satisfaction as a teacher & 4.51 & .559 \\
\hline \multicolumn{4}{|c|}{ Component 3: Affective } \\
\hline 15 & $\begin{array}{l}\text { I am willing to collaborate in school educational programs about } \\
\text { ICT. }\end{array}$ & 4.34 & .794 \\
\hline 16 & Students learn more easily when using ICT. & 4.57 & .756 \\
\hline 17 & I usually find teaching resources for my classes on the internet. & 4.28 & .954 \\
\hline & Affective Overall & 4.39 & .834 \\
\hline
\end{tabular}

As shown in Table 1, the teachers have a high level of positive overall attitude (Cognitive, $M=4.39$, $\mathrm{SD}=.661$ ) towards technology integration in education. The same goes to Behavioural, $\mathrm{M}=4.41, \mathrm{SD}=$ .631 and Affective, $\mathrm{M}=4.39, \mathrm{SD}=.834$. From the result, it shows that the teachers have a positive attitude towards the use of ICT and technology in their everyday lives as teachers. The results showed among the nine items in Cognitive component, two items share the highest mean value with 4.48, which are 'I would use internet in my classroom very often' and 'I am willing to receive training in the use of any computing resource to work in my classroom'. From this result, teachers felt cognitively positive towards integrating technology in their classroom as they feel open to the idea of attending any related trainings to improve their skills in teaching using technology, especially in relation with ICT. 
For the second component of Behavioural, there are five items with an overall mean value of 4.41 . From the five items, an item of 'In spite of limitations, I have a positive attitude towards the integration of computing resources in the teaching-learning process' gains the highest mean value of 4.62. Overall, teachers have a positive behavioural aspect of attitude towards integrating technology in their teachinglearning activities. The third component of Affective shows an overall mean value of 4.39. The highest percentage of mean for all three items is "Students learn more easily when using ICT" with 4.57. This showed that the teachers know that technology could make a difference in their teaching techniques.

\section{Comparative findings on ESL teachers'attitude towards technology integration by gender}

The comparative analysis results on teachers' attitude towards technology integration by their gender were presented in Table 2 below.

Table 2: ESL teachers' attitude towards technology integration by gender

\begin{tabular}{llllllllc}
\hline Factor & Groups & $\boldsymbol{N}$ & $\boldsymbol{M}$ & $\boldsymbol{S D}$ & $\boldsymbol{S E}$ & $\boldsymbol{d f}$ & $\boldsymbol{t}$ & $\boldsymbol{p}$ \\
\hline \multirow{2}{*}{ Attitude } & Male & 45 & 4.36 & .379 & .056 & 98 & -0.78 & 0.435 \\
& Female & 55 & 4.42 & .390 & .052 & 95 & -0.78 & 0.434 \\
\hline
\end{tabular}

From the table, it shows the mean scores and independent samples t-Test results of the ESL teachers' attitude towards technology integration by gender. From the score, it indicates there was no significant different for gender, $t(98)=-.78, p=.44$, despite female teachers $(M=55, S D=.38)$ attaining higher scores than male teachers $(\mathrm{M}=45, \mathrm{SD}=.39)$.

\section{Comparative findings on ESL teachers' attitude towards technology integration by age}

To examine whether there is a statistically significant difference between the teachers' attitude towards technology integration by their age, a One-way ANOVA and Tukey as a post-hoc was used. Prior to ANOVA, the homogeneity of the variance within the cases was tested with Levene's test. The test result $(\mathrm{p}=.910)$ showed that the distribution is parametric, thus not violating the assumption of normality. The One-Way Anova results in Table 3 showed that there was no significant difference between teachers' attitude regarding their age $\mathrm{F}(3,96)=.608, \mathrm{p}=.612$.

Table 3: ESL teachers' attitude towards technology integration by age

\begin{tabular}{lllllllll}
\hline $\boldsymbol{F a c t o r}$ & Groups & $\boldsymbol{N}$ & $\boldsymbol{M}$ & $\boldsymbol{S D}$ & $\boldsymbol{S E}$ & $\boldsymbol{d f}$ & $\boldsymbol{F}$ & $\boldsymbol{p}$ \\
\hline Attitude & 24 to 34 years old & 14 & 4.27 & .36 & .097 & 3 & .608 & .612 \\
& 35 to 45 years old & 61 & 4.41 & .36 & .046 & & & \\
& 46 to 56 years old & 7 & 4.33 & .41 & .16 & & & \\
& 56 years old and above & 18 & 4.39 & .35 & .083 & & & \\
\hline & Total & 100 & 4.38 & .36 & .036 & & & \\
\hline
\end{tabular}

\section{Discussion}

The study investigated the attitude of ESL teachers towards integrating technology in teaching and whether their attitude differs subject to the variables of gender and age. Many other factors like school settings may influence effective integration of technology in teaching and learning in an educational setting or even the national education policies. However, of all the factors, teachers have the most prominent role in technology integration in their teaching. Thus, improving teachers' attitude is critical 
to an effective integration of technology in school settings. However, there are some visible limitations of the study that require improvement. First, teachers' attitude is one factor that has an influence on teachers' technology integration during teaching and learning activities. Second, the results of the study cannot be generalised to other schools from different states because it was conducted in Sabah. Thus, the teachers' attitude levels from other states might produce different results altogether. The quantitative nature of the study is also another factor that might affect the results. Further research could use both qualitative and quantitative methods to explore factors that affect teachers' attitude towards technology integration. Despite all the limitations, the present study would contribute to the literature and might be useful to improve the technology integration, especially to the ESL teachers all over Malaysia.

The results of the study revealed that the ESL teachers have a high level of positive overall attitude towards integrating technology in teaching. This result corresponded with the findings of other studies (Mollaei, \& Riasati, 2013, Eyyam, et al., 2010; Lau \& Sim, 2008; Özdamli, et al., 2009). The findings also illustrated that there is no significant difference between teachers' attitude towards technology integration regarding their gender. This concurred with other research findings (Cavas, et al., 2009; Kusano, et al., 2013). The findings of the study also showed that there is no significant difference between teachers' technology integration regarding their age. This is contrary to some previous studies that argued that there is a significant difference between age and teachers' attitude towards ICT use (Cavas et al., 2009; Seraji et al., 2017). The studies showed that younger teachers' attitude towards computer is more positive and lower computer anxiety than older teachers. Findings by Lau and Sim (2008) also supported the claim that age is a significant factor in which in their study the higher age group teachers use computer technology more frequently than the younger teachers and are keen to adopt technology in their teaching.

\section{Conclusion}

This study shows that how ESL teachers in Sabah aspire to integrate technology in their teaching as indicated by their positive attitude towards the technology. To have teachers with a positive attitude towards technology benefits any school as the country moves forward towards Industrial Revolution 4.0 where technologies play a vital part in developing the nation. The results of the study showed that all the ESL teachers embrace the idea to integrate technology in their teaching. This positive attitude is an important sign of willingness towards an effective integration of technology. As for the findings of the present study, there are no significant differences regarding age. The same goes to gender, as it is not a determining factor in the attitude towards technology integration among the ESL teachers in Sabah. Thus, as a conclusion, ESL teachers in Sabah show a very positive attitude towards technology integration in their teaching activities. Besides that, factors of age and gender did not play significant factors towards the ESL teachers' technology integration, making it a great opportunity for relevant parties to implement any ICT related programs or policies in the future.

\section{References}

Abedalaziz, N., Shahrir Jamaluddin \& Chin, H. L. (2013). Measuring Attitude toward Computer and Internet Usage among Postgraduate Students in Malaysia. TOJET: The Turkish Online Journal of Educational Technology 12(2): 200-214.

Andrei, E. (2017). Technology in teaching English language learners: The case of three middle school teachers. TESOL Journal, 8(2), 409-431.

Belland, B. R. (2009). Using the theory of habitus to move beyond the study of barriers to technology integration. Computers \& Education, 52(2), 353-364.

Bozionelos, N. (2001). Computer anxiety: relationship with computer experience and prevalence. Computers in human behavior, 17(2), 213-224.

Cavas, B., Cavas, P., Karaoglan, B., \& Kisla T. (2009). A study on science teachers' attitude toward information and communication technologies in education. The Turkish Online Journal of Educational Technology, 8(2), 20-32. 
Chigona, A. (2015). Pedagogical shift in the twenty-first century: Preparing teachers to teach with new technologies. Africa Education Review, 12(3), 478-492.

Dias, P. C., \& Cadime, I. (2016). Effects of personal and professional factors on teachers' attitude towards inclusion in preschool. European Journal of Special Needs Education, 31(1), 111-123.

Drossel, K., Eickelmann, B., \& Gerick, J. (2017). Predictors of teachers' use of ICT in school-the relevance of school characteristics, teachers' attitude and teacher collaboration. Education and Information Technologies, 22(2), 551-573.

Edwards, L. (2016). Education, Technology and Higher Order Thinking Skills. Australian Association for Research in Education.

Eyyam, R., Meneviş, I., \& Doğruer, N. (2010). Perceptions of prospective teachers towards technology use in class. Procedia Social and Behavioral Sciences, 3, 88-93. doi: https://doi.org/10.1016/j.sbspro.2010.07.016

Gilakjani, A. P. (2017). A review of the literature on the integration of technology into the learning and teaching of English language skills. International Journal of English Linguistics, 7(5), 95106.

Gilakjani, A. P. \& Leong, L. M. (2012). EFL teachers' attitude toward using computer technology in English language teaching. Theory and Practice in Language Studies, 2(3), 630-636.

González-Carriedo, R., \& Esprívalo Harrell, P. (2018). Teachers' attitude toward technology in a twoway dual-language program. Computers in the Schools, 35(2), 111-133.

González-Sanmamed, M., Sangrà, A., \& Muñoz-Carril, P. C. (2017). We can, we know how. But do we want to? Teaching attitude towards ICT based on the level of technology integration in schools. Technology, Pedagogy and Education, 26(5), 633-647.

Gray, L., Thomas, N., \& Lewis, L. (2010). Teachers' Use of Educational Technology in US Public Schools: 2009. First Look. NCES 2010-040. National Center for Education Statistics.

Joo, Y. J., Park, S., \& Lim, E. (2018). Factors influencing preservice teachers' intention to use technology: TPACK, teacher self-efficacy, and technology acceptance model. Journal of Educational Technology \& Society, 21(3), 48-59.

Kim, C., Kim, M. K., Lee, C., Spector, J. M., \& DeMeester, K. (2013). Teacher beliefs and technology integration. Teaching and teacher education, 29, 76-85.

Krause, M., Pietzner, V., Dori, Y. J., \& Eilks, I. (2017). Differences and developments in attitude and self-efficacy of prospective chemistry teachers concerning the use of ICT in education. Eurasia Journal of Mathematics, Science and Technology Education, 13(8), 4405-4417.

Kusano, K., Frederiksen, S., Jones, L., Kobayashi, M., Mukoyama, Y., Yamagishi, T., ... \& Ishizuka, H. (2013). The effects of ICT environment on teachers' attitude and technology integration in Japan and the US. Journal of Information Technology Education: Innovations in Practice, 12(1), 29-43.

Lau, B. T., \& Sim, C. H. (2008). Exploring the extent of ICT adoption among secondary school teachers in Malaysia. International Journal of Computing and ICT Research, 2(2), 9-36.

Meelissen, M. R., \& Drent, M. (2008). Gender differences in computer attitude: Does the school matter?. Computers in Human behavior, 24(3), 969-985.

Mollaei, F., \& Riasati, M. J. (2013). Teachers' perceptions of using technology in teaching EFL. International Journal of Applied Linguistics and English Literature, 2(1), 13-22.

Özdaml, F., Hürsen, Ç., \& Özçinar, Z. (2009). Teacher candidates' attitude towards the instructional technologies. Procedia - Social and Behavioral Sciences, 1(1), 455-463. doi: https://doi.org/10.1016/j.sbspro.2009.01.082

Rana, N. (2016). A Study to Assess Teacher Educators' Attitude towards Technology Integration in Classrooms. Mier Journal of Educational Studies, Trends And Practices, 2(2).

Sánchez, A. B., Marcos, J. J. M., González, M. A., \& GuanLin, H. (2012). In service teachers' attitude towards the use of ICT in the classroom. Procedia-Social and Behavioral Sciences, 46, 13581364.

Semerci, A., \& Aydin, M. K. (2018). Examining High School Teachers' Attitude towards ICT Use in Education. International Journal of Progressive Education, 14(2), 93-105.

Seraji, N.E., Ziabari, R.S., \& Rokni, S.J.A. (2017). Teacher's attitude towards educational technology in English language institutes. International Journal of English Linguistics, 7(2), 176-185. doi: https://doi.org/10.5539/ijel.v7n2p176 
DOI: https://doi.org/10.47405/mjssh.v5i12.566

Tarman, B., Kilinc, E., \& Aydin, H. (2019). Barriers to the Effective Use of Technology Integration in Social Studies Education. Contemporary Issues in Technology and Teacher Education, 19(4), 736-753.

Teo, T., Milutinović, V., \& Zhou, M. (2016). Modelling Serbian pre-service teachers' attitude towards computer use: A SEM and MIMIC approach. Computers \& Education, 94, 77-88.

Tondeur, J., Pareja Roblin, N., van Braak, J., Voogt, J., \& Prestridge, S. (2017). Preparing beginning teachers for technology integration in education: Ready for take-off?. Technology, Pedagogy and Education, 26(2), 157-177.

Toh, Y. (2016). Leading sustainable pedagogical reform with technology for student-centred learning: A complexity perspective. Journal of Educational Change, 17(2), 145-169.

Zyad, H. (2016). Integrating Computers in the Classroom: Barriers and Teachers' Attitude. International Journal of Instruction, 9(1), 65-78. 